\title{
Determination of Efficient Methods and Appropriate Time of Seed Harvesting for Panicum coloratum at Teppi Agricultural Research Center, Southwester Ethiopia
}

ISSN: 2637-7659

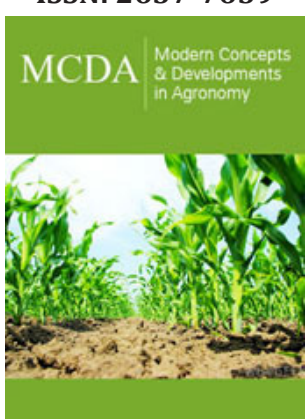

*Corresponding author: Gezahegn Mengistu, Teppi agricultural Research Center, P.O. Box, 34, Teppi, Ethiopia

Submission: 㱔 May 09, 2020

Published: 海June 29, 2020

Volume 6 - Issue 4

How to cite this article: Gezahegn Mengistu, Ararsa Bogale, Dereje Tulu, Melkam Aleme, Solomon Mengistu. Impact ofVermicompostFertilizer on Spinach Yield and Nutritional Components. Mod Concep Dev Agrono. 6(4). MCDA. 000644. 2020. DOI: 10.31031/MCDA.2020.06.000644

Copyright@Gezahegn Mengistu, This article is distributed under the terms of the Creative Commons Attribution 4.0 International License, which permits unrestricted use and redistribution provided that the original author and source are credited.

\author{
Gezahegn Mengistu${ }^{1}$, Ararsa Bogale ${ }^{1}$, Dereje Tulu ${ }^{1}$, Melkam Aleme $^{1}$ and \\ Solomon Mengistu ${ }^{2}$ \\ ${ }^{1}$ Teppi agricultural Research Center, Teppi, Ethiopia \\ ${ }^{2}$ Holeta agricultural research center, Holeta, Ethiopia
}

\begin{abstract}
The aims of this study were to determine appropriate time and efficient techniques of harvesting methods for Panicum Coloratum forage. The experiment was designed in randomized complete block design (RCBD,) in $4 \times 4$ factorial combinations of harvesting methods (mowing, sweating, shaking and sweeping) and time harvesting $\left(14^{\text {th }}, 21^{\text {th }}, 28^{\text {th }}\right.$ and $35^{\text {th }}$ days) after full anthesis. The experiment was replicated four times. The Results revealed that the mean number of inflorescences per $\mathrm{M}^{\mathrm{s}}$, number of racemes per inflorescence, number of spikelet per raceme f were significantly different across the years. Seed yield and seed germination percentage were affected by different harvesting methods and time of harvesting and also influenced by their interactions. The sweating method gave more seed yield 633 and $618 \mathrm{~kg} / \mathrm{ha}$ on the $28^{\text {th }}$ and $35^{\text {th }}$ days of harvesting with 66 and 64 germination percentages respectively. In conclusion, smallholder farmers or commercial seed producers can produce optimum seed yield and quality by sweating method at 28 or 35 days of harvesting after full anthesis.
\end{abstract}

Keywords: Harvesting; Method; Panicum coloratum; Time

\section{Introduction}

The main constraint to livestock production in developing countries is the scarcity and fluctuation of the quality and quantity of the year-around animal feed supply [1]. FAO [2] reported that feed deficiency in Ethiopia is 9 percent as Dry matter (DM), while Metabolizable energy (ME) and Crude protein (CP) deficiencies are 45 percent and 42 percent respectively. Adequate supply of livestock feed is crucial to the livelihoods of livestock producers. Sowing a new pasture or improving an existing natural pasture requires a reliable source of high quality seed or vegetative material of species recommended and adapted for the area. Seed production of forage species is less developed stage in the tropics and subtropics than in temperate regimes [3]. The availability of forage seed is limited though the demand for quality forage seed is increasing from time to time. Producing forage seed is critical since importing seed is not economically sound.

Colored Guine grass (Panicum coloratum L.) is a tropical fine-stemmed and leafy grass taxonomically classified as Panicoideae sub-family species and can provide good quality forage for livestock [4]. It is useful for strip planting or mixed pastures in areas below $2400 \mathrm{~m}$ altitude with more than $500 \mathrm{~mm}$ annual rainfall [5]. Panicum coloratum tends to be troublesome in practical seed production including no uniform seed maturation, loss of seed due to shattering before maturity and loss of immature seed due to pest attack (ants and birds). Wider use of these promising forage species is based on sustained supply of planting material, especially seed, which is more convenient to transport and in sowing operations. Successful seed production on the other hand requires knowledge of forage seed crop husband- 
ry techniques such as careful site selection, seedbed preparation fertilizer type and rate of application, sowing technique including subsequent crop management, quality control including requiring off-type plants, proper harvesting time and technique and seed processing and seed storage.

Proper choice of harvest time is important. It is also important that choosing of the method of harvest and care should be required for purity standards and with minimum wastage of seed and time. With knowledge of seed-production requirements, potential seed producers from the private or public sector can decide whether such an enterprise would be technically and economically viable. Thus, studies on appropriate forage seed harvesting management techniques help fully exploit the seed potential of cultivated forage varieties. Choosing an appropriate time and method of seed harvest is crucial in pasture seed husbandry of sown pastures. In the current study, different methods of seed harvesting and appropriate time of harvest were examined for Panicum coloratum grass species to determine the optimum.

\section{Material and Methods}

\section{Description of the study area}

The experiment was carried out during 2016, 2017 and 2018 main cropping season at Teppi Agricultural Research Center. The center is located at $7^{\circ} 08^{\prime}$ latitude $35^{\circ} 18^{\prime}$ longitude about $610 \mathrm{kms}$ south west of Addis Ababa at the elevation of 1200 meters above sea level. The average annual temperature is $23{ }^{\circ} \mathrm{C}$ with mean minimum and maximum of $15^{\circ} \mathrm{C}$ and $30{ }^{\circ} \mathrm{C}$, respectively. The area has an annual average rainfall of $1630 \mathrm{~mm}$, of which the majority falls during May-October [6]. The major farming system is mixed crop-livestock production mainly with perennial cash crops like Coffee, Spices and Chat (Catha edulis). The major livestock raised in the study area are cattle, sheep, goats and poultry. Maize, Sorghum, Enset (Ensete ventricosum) and horticultural crops are the main food crops grown in the study area [7].

\section{Experimental design, treatment and establishment}

The experiment was arranged in randomized complete block design (RCBD) in factorial combinations of four harvesting methods and four harvesting times for panicum coloratum replicated four times. The harvesting methods were considered as main-plot and consists

1. (Mowing) hand plucking/mowing of ripened panicle,

2. (Shaking) shaking the panicle once daily allowing the ripe seeds to fall in nylon net collecting bags attached to stems,

3. (Sweeping) sweeping of fallen seeds from the ground after previously cutting of the dry stems and

4. (Sweating) mowing of panicle with half-mature seed and sweating it in the shade.
Time of harvesting was considered as sub-plots and scheduled by number of days after full heading stage (100\% anthesis). Treatments were described as harvest two weeks (14 days) after full heading, three weeks (21days), four weeks (28 days), and five weeks(35days). Subsequent seed harvests were taken when stems of plot reached the same phenological stage of the first year harvest over the year of evaluation. The experiment consisted of sixty four experimental plots and each plot had area of $12 \mathrm{~m}^{2}\left(3^{*} 4 \mathrm{~m}\right), 10$ rows equally spaced, $4 \mathrm{~m}$ in length and $30 \mathrm{~cm}$ apart. A clean, well prepared seed bed was used to plant the experiment. The seeding rate was $8 \mathrm{~kg} / \mathrm{ha}$ drilled in the rows at the beginning of the main rain season on mid-June in the first year. In the second and third year the grass was harvested and cleaned during the start of the main rainy season. Diammonium phosphate (DAP) fertilizer was applied at the rate of $100 \mathrm{~kg} /$ ha for optimum growth and production. Weeds were removed by hoeing.

\section{Data collection}

Data collected were components of seed yield number of inflorescence $/ \mathrm{m}^{2}$, number of raceme per inflorescence, number of spikelet per raceme, seed yield and 1000 seed weight) and seed viability (germination percentage) and defined as:

A. Number of inflorescences per meter square: Inflorescences were compounds panicles having two or more series of branches, and the number of inflorescences were taken from individual plants from meter square area in each plot.

B. Number of raceme per inflorescence: The number of branches on the inflorescence or short stalks along the main stem in which the flowers are born and determined from 10 plants in each plot within the same sampling area.

C. Number of spikelet per raceme: The number of basic unit of grass flower that makeup the compound inflorescences of grasses and was counted from 10 randomly selected inflorescences in each plot at harvest.

D. Seed yield (kg/ha): The quantity of seed $(\mathrm{kg})$ yield obtained from $1 \mathrm{~m}^{2}$ which was converted to hectare of land $\left(10000 \mathrm{~m}^{2}\right)$.

E. Thousand seed weight (g): The weight of seed obtained from thousand seeds measured with sensitive electronic balance and carried out when seed moisture content (determined by testing a small seed sample by moisture meter) was approximately $12 \%$.

F. Seed germination test (\%): The maximum germination potential of the seed out of 100 seeds.

\section{Data analysis}

Data were analyzed using general linear model of statistical analysis using SAS 9.3 statistical software. Least significant difference (LSD) test was employed for variables whose F-values declared significant difference $(\mathrm{P}<0.05)$. The statistical model for data analysis was; 


$$
Y i j k=\mu+M i+T j+M T i j+E i j k
$$

Where:

Yijk=Response variable, $\mu=$ Overall mean,

Mi=fixed effect of harvesting method $\mathrm{i}=$ mowing, shaking, sweating and sweeping

Tj=fixed effect of harvesting time $\mathrm{j}=14$ days after full heading, 21, 28 and 35days.

MTij=the interaction effect of harvesting method and time of harvesting.

Eijk=Random error

\section{Result and Discussion}

\section{The number of inflorescence, racemes and spikelet}

The means number of inflorescences per $\mathrm{M}^{2}$, number of racemes per inflorescence, number of spikelet per raceme for Panicum coloratum during the three consecutive experimental years are indicated in (Table1). The means number of inflorescence count per unit square were significantly $(\mathrm{p}<0.01)$ different across the years. The result showed that in the $2^{\text {nd }}$ year the highest number of inflorescence (162.73) was recorded whereas in the $3^{\text {rd }}$ and $1^{\text {st }}$ years records with mean values of 149.17 and 137.73, respectively. The more number of inflorescence records in the second year than $3^{\text {rd }}$ year and the establishment year $\left(1^{\text {st }}\right.$ year $)$ might be due to more number of tillers emerged after cutting in the $2^{\text {nd }}$ year.

Table 1: The Means of inflorescences per m2, number of raceme per inflorescence, number of spikelet per raceme for Panicum coloratum for three consecutive years at Teppi Agricultural Research Center.

\begin{tabular}{|c|c|c|c|}
\hline Years & Inflorescence/M2 & $\begin{array}{c}\text { Raceme/Inflo- } \\
\text { rescence }\end{array}$ & Spikelet/ Raceme \\
\hline 2016 & $149.17 \mathrm{~b}$ & $40.51 \mathrm{~b}$ & $343.90 \mathrm{ab}$ \\
\hline 2017 & $162.73 \mathrm{a}$ & $44.29 \mathrm{a}$ & $348.97 \mathrm{a}$ \\
\hline 2018 & $137.73 \mathrm{c}$ & $42.00 \mathrm{ab}$ & $331.09 \mathrm{~b}$ \\
\hline Mean & 149.87 & 42.26 & 344.66 \\
\hline CV & 11.33 & 22.57 & 13.39 \\
\hline Sig & $* *$ & $\mathrm{~ns}$ & $\mathrm{~ns}$ \\
\hline
\end{tabular}

Means bearing different superscript letter along the column differ significantly $(\mathrm{P}<0.05)$.

In agreement with study done by Assefa et al. [8] on effect of methods and dates of clearing regrowth of Rhodes (Chlorisgayana) and Colored Guinea grasses (Panicumcoloratum) on seed productivity suggested that well established grass would continuous to perform well in the subsequent production seasons or years. Study done by Sousa et al. [9] suggested that, the combination of cutting management and fertilizer application encourage production of new tillers and promoting the uniform development of dense inflo- rescences populations are observed on Xaraes palisade grass. According to report of Sbrissia et al. [10], the formation and development of tillers for palisade grass determines panicle number which is a key component of seed yield. The lower mean number of inflorescences counted in the 3rd year could be due to non- productive tillers as the age of the grass get older. The current result indicated that number of racemes per inflorescence, number of spikelet per raceme count showed no difference across the years.

\section{Seed yield, thousand seed weight and germination per- centage of Panicum coloratum harvested in different methods}

The effect of different harvesting methods on seed yield, thousand seed weight and germination percentage in each year and their overall means of Panicum coloratum for three consecutive experimental years are shown in (Table 2). Seed yield was significantly $(\mathrm{P}<0.001)$ different when it was harvested by the four different methods across years. However, it was also showed significant $(\mathrm{P}<0.001)$ interaction effect with methods and times of harvesting. The overall mean seed yield obtained from sweating method (467) was higher than mowing (400), shaking (311) and sweeping (238). The higher seed yield from sweating might be due to efficiency of the harvesting method. The sweating method probably results in minimum seed loss. In agreement with Abebe et al. [11] total seed yield harvested from Andropogon gayanus grass significantly affected by harvesting method. In contrast to this, Mengistu et al. [5] reported that direct mowing is more efficient harvesting method for seed recovery for Panicum grass species. The mean seed yield of panicum coloratum obtained in different methods of harvesting in the present study was higher than $145 \mathrm{~kg} / \mathrm{ha}$, which was reported by Assefa et al. [8]. Method of harvesting did not significantly ( $P>0.05)$ affect thousand seed weight of Panicum coloratom. In this study, methods of harvest $(\mathrm{P}<0.001)$ are affected seed germination percentage and the interaction effect with time of harvesting. The highest germination percentage was recorded on sweating (54\%) whereas the lowest recorded on sweeping (31\%) method of harvesting. Carla et al. (2017) suggested that the quality of seeds of forage species can be influenced by different harvesting method used. Germination percentage had also showed similar trend with seed yield.

\section{Seed yield, thousand seed weight and germination per- centage of Panicum coloratum harvested at different times}

The current study showed that the effect of harvesting times significantly affected the seed yield (Table 2 ). The overall seed yield ( $\mathrm{kg} / \mathrm{ha}$ ) obtained on the $35^{\text {th }}$ days (493) and on the $28^{\text {th }}$ days (481) were the highest values and statistically similar. On the contrary, the lowest seed yield (153) was produced on the $14^{\text {th }}$ days of harvesting after full anthesis. 
Table 2: Means of Seed yield (kg/ha), Thousand seed weight $(\mathrm{g})$ and Seed germination percentage for Panicum coloratum during the three consecutive experimental periods.

\begin{tabular}{|c|c|c|c|c|c|c|c|c|c|c|c|c|}
\hline \multirow{2}{*}{ Method of harvesting } & \multicolumn{4}{|c|}{ Seed Yield (kg/ha) } & \multicolumn{4}{|c|}{1000 Seed Weight (g) } & \multicolumn{4}{|c|}{ Germination (\%) } \\
\hline & Year 1 & Year 2 & Year 3 & Mean & Year1 & Year 2 & Year 3 & Mean & Year1 & Year 2 & Year 3 & Mean \\
\hline Mowing & $411^{a}$ & $426^{\mathrm{b}}$ & $361^{\mathrm{a}}$ & $400^{\mathrm{b}}$ & 1.7 & 1.95 & 2.07 & 1.91 & $46^{\mathrm{b}}$ & $52^{\mathrm{a}}$ & $45^{\mathrm{b}}$ & $47^{b}$ \\
\hline Shaking & $333^{\mathrm{b}}$ & $332^{\mathrm{c}}$ & $268^{\mathrm{b}}$ & $311^{\mathrm{c}}$ & 1.83 & 2.05 & 1.98 & 1.89 & $49^{\mathrm{ab}}$ & $54^{\mathrm{a}}$ & $51^{\mathrm{ab}}$ & $52^{\mathrm{ab}}$ \\
\hline Sweeping & $240^{c}$ & $283^{c}$ & $191^{\mathrm{c}}$ & $238^{\mathrm{d}}$ & 1.73 & 1.81 & 186 & 1.84 & $27^{\mathrm{c}}$ & $35^{\mathrm{b}}$ & $31^{\mathrm{c}}$ & $31^{\mathrm{c}}$ \\
\hline Sweating & $459^{a}$ & $531^{\mathrm{a}}$ & $409^{a}$ & $467^{\mathrm{a}}$ & 1.83 & 1.96 & 1.99 & 1.95 & $53^{\mathrm{a}}$ & $57^{\mathrm{a}}$ & $54^{\mathrm{a}}$ & $54^{a}$ \\
\hline $\mathrm{CV}$ & 23.9 & 18.43 & 28.08 & 19.51 & 13.13 & 13.05 & 13.16 & 7.35 & 16.14 & 14.12 & 13.25 & 13.08 \\
\hline$P$ value & 0.01 & 0.001 & 0.001 & 0.001 & 0.27 & 0.16 & 0.18 & 0.14 & 0.01 & 0.01 & 0.01 & 0.01 \\
\hline Sig & $* *$ & $* * *$ & $* * *$ & $* * *$ & ns & ns & ns & ns & $* *$ & $* *$ & $* *$ & $* *$ \\
\hline \multicolumn{13}{|l|}{ Harvesting Time } \\
\hline $14^{\text {th }}$ day & $173^{\mathrm{c}}$ & $164^{c}$ & $123^{c}$ & $153^{\mathrm{c}}$ & $1.43^{c}$ & 1.84 & 2.04 & $1.80^{\mathrm{b}}$ & $24^{\mathrm{c}}$ & $31^{\mathrm{c}}$ & $26^{c}$ & $27^{\mathrm{c}}$ \\
\hline $21^{\text {th }}$ day & $306^{\mathrm{b}}$ & $321^{\mathrm{b}}$ & $240^{\mathrm{b}}$ & $289^{b}$ & $1.69^{\mathrm{b}}$ & 1.93 & 1.98 & $1.83^{\mathrm{b}}$ & $35^{\mathrm{b}}$ & $42^{\mathrm{b}}$ & $40^{\mathrm{b}}$ & $39^{b}$ \\
\hline $28^{\text {th }}$ day & $466^{\mathrm{a}}$ & $561^{\mathrm{a}}$ & $416^{\mathrm{a}}$ & $481^{\mathrm{a}}$ & $1.91^{\mathrm{a}}$ & 2.05 & 1.97 & $1.98^{\mathrm{a}}$ & $55^{\mathrm{a}}$ & $64^{\mathrm{a}}$ & $54^{\mathrm{a}}$ & $58^{\mathrm{a}}$ \\
\hline $35^{\text {th }}$ day & $501^{\mathrm{a}}$ & $526^{a}$ & $451^{\mathrm{a}}$ & $493^{\mathrm{a}}$ & $2.06^{\mathrm{a}}$ & 1.96 & 1.92 & $1.98^{\mathrm{a}}$ & $59^{a}$ & $61^{\mathrm{a}}$ & $58^{\mathrm{a}}$ & $59^{a}$ \\
\hline \multicolumn{13}{|l|}{$\mathrm{CV}$} \\
\hline P-value & 0.0001 & 0.001 & 0.001 & 0.01 & 0.001 & 0.6 & 0.64 & 0.001 & 0.001 & 0.001 & 0.001 & 0.001 \\
\hline Sig & $* * *$ & *** & $* * *$ & $* *$ & $* * *$ & ns & ns & $* * *$ & $* * *$ & $* * *$ & $* * *$ & $* * *$ \\
\hline \multicolumn{13}{|l|}{ Interaction Effect } \\
\hline $\mathrm{Hm} * \mathrm{Ht}$ & 0.04 & 0.002 & 0.05 & 0.04 & 0.25 & 0.22 & 0.5 & 0.35 & 0.009 & 0.002 & 0.01 & 0.009 \\
\hline
\end{tabular}

Means bearing different superscript letter along the column differ significantly $(\mathrm{P}<0.01, \mathrm{P}<0.001)$; Hm=harvesting method; $\mathrm{Ht}=$ harvesting time; $\mathrm{CV}=$ coefficient of variation, sig=significant; ns=non- significant difference $\mathrm{p}>0.05,{ }^{* * *}=$ significant difference $\mathrm{p}<0.001$.

In contrast to harvesting methods, harvesting times significantly affected thousand seed weight. The maximum 1000-seed weight was recorded on $35^{\text {th }}$ and $28^{\text {th }}$ (1.98) days, whereas the lowest minimum 1000 -seed weight attained on $14^{\text {th }}$ days of harvesting (1.84). Time of harvesting affected germination percentage. The best germination percentage and recovery of good quality seed was attained on $28^{\text {th }}(72)$ and $35^{\text {th }}(74)$ days of harvesting after peak anthesis. The lowest germination percentage was on $14^{\text {th }}$ day harvest after peak anthesis and this would indicate seed immaturity and low viability.

\section{Interaction effect harvesting methods and time of har- vesting on seed yield of Panicum coloratum}

There was a significant interaction between different harvesting methods and time of harvesting of Panicum coloratum (Table 3). The overall mean result indicated that highest seed yield $(633 \mathrm{~kg} /$ ha) was obtained by sweating over other harvesting methods at $28^{\text {th }}$ days and the value was also statistically similar with the $35^{\text {th }}$ harvesting days $(61 \mathrm{~kg} / \mathrm{ha})$.This was followed by sweeping by $35^{\text {th }}$ days ( 570 ) and then by mowing method. The lowest seed yield $(133.33 \mathrm{~kg} / \mathrm{ha})$ was attained at the 14 th days of harvesting by sweeping. The sweeping method appeared to be the least efficient even if harvesting time is undertaken at different weeks. This could be associated with loss of seeds in the cracked experimental plot. Abebe et al. [11] suggested that low seed yield of Andropogon gayanus a harvested by sweeping could be due to losses of seed by wind and small insects before harvesting. Lowest seed yield obtained on the $14^{\text {th }}$ days harvesting time might be due to the immaturity stage of Panicum coloratum so that small amount of seeds were recovered the maturity stage.

Table 3: Mean Interaction effects of harvesting method and time of harvesting on seed yield for Panicum coloratum during the consecutives experimental years.

\begin{tabular}{|c|c|c|c|c|}
\hline $\begin{array}{c}\text { Harvesting } \\
\text { Methods }\end{array}$ & $\mathbf{1 4}^{\text {th }}$ day & $\mathbf{2 1}^{\text {th }}$ day & $\mathbf{2 8}^{\text {th }}$ day & $\mathbf{3 5}^{\text {th }}$ day \\
Mowing & $163^{\text {hi }}$ & $336^{\text {ef }}$ & $530^{\text {bc }}$ & $570^{\text {ab }}$ \\
\hline Shaking & $126^{\mathrm{i}}$ & $234^{\text {gh }}$ & $431^{\text {de }}$ & $453^{\text {cd }}$ \\
\hline Sweeping & $133^{\mathrm{i}}$ & $159^{\text {hi }}$ & $329^{\text {fg }}$ & $330^{\text {fg }}$ \\
\hline Sweating & $191^{\text {hi }}$ & $484^{\text {def }}$ & $633^{\text {a }}$ & $618^{\text {ab }}$ \\
\hline
\end{tabular}

Means bearing different superscript letter along the column differ significantly $(\mathrm{P}<0.05)$.

\section{Interaction effect of harvesting methods and time of har- vesting on 1000-seed weight of Panicum coloratum}

There was a significant interaction effect of 1000-seed weight $(\mathrm{P}<0.01)$ between different harvesting methods and time of har- 
vesting of Panicum coloratum (Table 4). The maximum 1000-seed weight $(2.11 \mathrm{~g})$ was obtained by sweating over other harvesting method at the $28^{\text {th }}$ days whereas the lowest value $(1.73 \mathrm{~g}$ ) was on $14^{\text {th }}$ days by sweeping method after full anthesis.

Table 4: Mean Interaction effects of harvesting method and time of harvesting for 1000 seed weight (gram) of Panicum coloratum during the consecutives experimental years.

\begin{tabular}{|c|c|c|c|c|}
\hline $\begin{array}{c}\text { Harvesting } \\
\text { Methods }\end{array}$ & \multicolumn{5}{c|}{ Harvesting Time (weeks) } \\
\hline Mowing & 1.82 & 1.81 & 1.95 & 2.06 \\
\hline Shaking & 1.8 & 1.85 & 2.01 & 1.91 \\
\hline Sweeping & 1.73 & 1.76 & 1.94 & 1.92 \\
\hline Sweating & 1.79 & 1.94 & 2.11 & 2.04 \\
\hline
\end{tabular}

Means bearing different superscript letter along the column differ significantly $(\mathrm{P}<0.01)$.

\section{Interaction effect of harvesting methods and time of harvesting on germination percentage of Panicum color- atum}

The Interaction effect of method of harvesting and time of harvesting on germination percentage of Panicum coloratum of the current study result is shown in (Table 5). Accordingly, The mean germination percentage recorded in mowing method at the $28^{\text {th }}$ and $35^{\text {th }}$ days of harvesting by mowing, sweating and shaking harvesting methods gave statistically similar germination.This might be attributed to optimum seed maturity of Panicum coloartum reached $28^{\text {th }}$ and $35^{\text {th }}$ days after full anthesis. The lowest seed germination percentage of Panicum coloratum was attained on $14^{\text {th }}$ days of harvesting by sweeping method of harvesting. Simon et al. [12] reported that immature seeds had higher initial seed moisture content, less developed, lighter, and as a result less viable than mature seeds [13]. The germination percentages observed by different harvesting methods (sweating, mowing and shaking) harvested at $28^{\text {th }}$ and $35^{\text {th }}$ days of harvesting times were higher than other country acceptable standards 60\% [8].

Table 5: Mean Interaction effects of harvesting method and time of harvesting on germination percentage for Panicum coloratum during the consecutives experimental years.

\begin{tabular}{|c|c|c|c|c|}
\hline $\begin{array}{c}\text { Harvesting } \\
\text { Methods }\end{array}$ & \multicolumn{5}{|c|}{ Harvesting Time (weeks) } \\
\hline Mowing & $\mathbf{1 4}^{\text {th }}$ day & $\mathbf{2 1}^{\text {th }}$ day & $\mathbf{2 8}^{\text {th }}$ day & $\mathbf{3 5}^{\text {th }}$ day \\
\hline Shaking & $27^{\text {ef }}$ & $34^{\text {cde }}$ & $65^{\mathrm{a}}$ & $65^{\mathrm{a}}$ \\
\hline Sweeping & $23^{\mathrm{g}}$ & $22^{\mathrm{c}}$ & $70^{\mathrm{a}}$ & $66^{\mathrm{a}}$ \\
\hline Sweating & $34^{\text {de }}$ & $52^{\mathrm{b}}$ & $33^{\mathrm{e}}$ & $41^{\text {cd }}$ \\
\hline
\end{tabular}

Means bearing different superscript letter along the column differ significantly $(\mathrm{P}<0.01)$.

\section{Conclusion}

Harvest methods and time of harvesting affected both seed yield and seed germination percentage in this study. Among dif- ferent methods and times of harvesting, the sweating method attained the best seed yield 633 and $618 \mathrm{~kg} / \mathrm{ha}$ when it was harvested at $28^{\text {th }}$ and $35^{\text {th }}$ days of harvesting after full anthesis, respectively. The study also showed that high germination percentage was obtained by shaking and sweating with no significant variation observed. Hence, harvesting Panicum coloratum by sweating method of seed harvesting at $28^{\text {th }}$ days of harvesting time gave better seed yield with optimum seed quality (germination percentage). This is valuable information for forage seed producers in this country.

\section{Data Availability}

The data sets used to support the findings of this study are available from the corresponding author up on request.

\section{Acknowledgement}

The authors are greateful to Ethiopian Institute of Agricultural Research, Livestock Research Directorate and Animal Feed and Nutrition Research Program organizers for funding this research. All members of center livestock research process who involved in field experimentation and data collection throughout the experimental period also highly acknowledged by the authors.

\section{References}

1. Alemayehu M, Gezahegn K, Getnet A, Fekede F (2016) Improved forage crops production strategies in Ethiopia: A review. Acad Res J Agri Sci Res 4(6): 285-296.

2. FAO (2018) Ethiopia: Report on feed inventory and feed balance. Rome, Italy, p. 160.

3. Gbenou B, Adjolohoun S, Houndjo DBM, Ahoton L, Saidou A, et al. (2018) Practical aspects of grass forage seed production and quality with particular reference to planting row spacing and nitrogen fertilization in tropical regions: A review. International Journal of Biological and Chemical Sciences 12(1): 508-518.

4. Wouw MVD, Jorge MAB, Bierwirth J, Hanson J (2008) Characterization of collection of perennial Panicum species. Tropical Grasslands 42: 40-53.

5. Mengistu A, Kebede G, Assefa G, Feyissa F (2017) Descriptions and characteristics of cultivated forage crops growing under different Agro-Ecological Zones in Ethiopia. Inter J Agri Biosci 6(5): 238-247.

6. Shamil A, Abebe G, Wakjira G (2017) Study on performance of tomato (Lycopersicon Esculentum Mill.) varieties under off season condition at Tepi south western Ethiopia. Greener J Agric Sci 7(5): 120-125.

7. Gezahegn M, Endale Y, Yadessa, Dereje T, Melkam A, et al. ( 2017) Survey on livestock production system characterization in bench-maji, sheka and mejenger zones, South Western Ethiopia. IJRAS 4(5): 231-239.

8. Assefa G, Kebede G, Feyissa F (2003) Effect of methods and dates of clearing regrowths of rhodes (Chloris gayana) and colored guinea grasses (Panicum coloratum) on seed productivity, $11^{\text {th }}$ ESAP Proceedings, Ethiopian Society of Animal production, Ethiopia, p. 297.

9. Sousa BML, Nascimento júnior D, Rodrigues CS, de Freitas Monteiro HC, da Silva SC, et al. (2011) Morphogenetic and structural characteristics of xaraes palisadegrass submitted to cutting heights. Revista Brasileira de Zootecnia 40(1): 53-59.

10. Sbrissia AF, Da silva SC, Sarmento DOL, Molan LK, Andrade FME, et al. (2010) Tillering dynamics in palisadegrass swards continuously stocked by cattle. Plant Ecology 206(2): 349-359.

11. Abebe A, Faji M, Mengistu S (2016) Determination of appropriate, time and efficient method of seed harvesting from andropogongayanus at 
benishangul-gumuz, Western Ethiopia. Forage Res 42(3): 143-148.

12. Simon U, Hare MD, Kjaersgaard B, Clifford PT, Hampton JG, et al. (1997) Harvest and post- harvest management of forage seed crops: Forage production. Fairey DT, Hampton JG (Eds.), Cab International, UK.
13. Quadros DG de, Andrade AP, Oliveira GC de, Oliveira EP, Moscon ES (2012) Componentes da produção e qualidade de sementes dos cultivares Marandú e Xaraés de Brachiaria brizantha (Hochst. ex A. Rich.) Stapf colhidas por varredura manual ou mecanizada. Semina: Ciências Agrárias 33(5): 2019-2028.

For possible submissions Click below: 